\title{
Pengembangan modul pembelajaran zat adiktif dan psikotropika berbasis scientific approach dengan crossword puzzle
}

\author{
Siska Arimadona ${ }^{1 *}$, Rini Silvina ${ }^{2}$ \\ Pendidikan Biologi, STKIP Ahlussunnah Bukittinggi \\ Kota Bukittinggi, Sumatera Barat, Indonesia \\ *Coressponding author email: siskaarimadona@gmail.com
}

\begin{tabular}{ll}
\hline Artikel info \\
\hline Received $: 7$ Agustus 2018 \\
Revised $: 10$ Maret 2019 \\
Accepted $: 19$ April 2019
\end{tabular}

Kata kunci:

Crossword puzzle

Modul

Scientific approach

Zat Adiktif

\begin{abstract}
ABSTRAK
Pengemasan modul pembelajaran yang menarik akan mengakomodasi pencapaian kompetensi siswa. Penelitian ini bertujuan untuk mengembangkan modul pembelajaran berbasis scientific approach dengan crossword puzzle pada materi zat adiktif dan psikotropika. Jenis penelitian yang digunakan adalah penelitian pengembangan dengan model pengembangan ADDIE (Analysis, Design, Development, Implementation, dan Evaluation). Instrumen pengumpulan data yang digunakan adalah lembar validasi, lembar respon oleh guru dan siswa. Statistika deskriptif digunakan sebagai teknik analisis data pada penelitian ini. Hasil penelitian ini menunjukkan bahwa modul yang dikembangkan dinyatakan valid dan layak untuk digunakan dalam pembelajaran pada materi zat adiktif dan psikotropika bagi siswa SMP.
\end{abstract}

\section{ABSTRACT}

Keywords:

Crossword puzzle

Module

Scientific approach

Addictive Substances

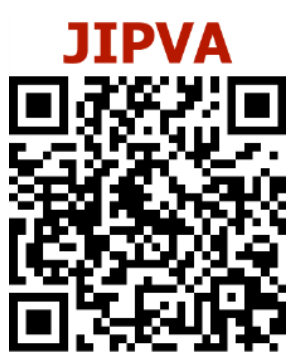

Developing learning module addictive and psychotropic substances based on scientific approach combined with crossword puzzle. Interesting learning material packaging will accommodate the achievement of students competencies. The aim of this study was to develop the module based on the scientific approach with crossword puzzle variation. ADDIE development model was used in this research. The data was carried out by validation instrument and questionnaire of teacher and student response. A quantitativedescriptive data analyses technique was used in this research. The result shows that the developed module is valid and feasible to use in the learning process in addictive substances and psychotropic topics for junior high school students.

\section{https://doi.org/10.31331/jipva.v3i1.661}

How to Cite: Arimadona, S., \& Silvina, R. (2019). Modul pembelajaran berbasis scientific approach dengan variasi crossword puzzle. JIPVA (Jurnal Pendidikan IPA Veteran), 3(1), 62-75. doi: https://doi.org/10.31331/jipva.v3i1.661 


\section{PENDAHULUAN}

Siswa harus dikodisikan untuk aktif dalam pembelajaran sehingga dapat menkonstruksi pengetahuan dan konsep mereka sendiri dalam rangka mencapai tujuan pembelajaran yang telah ditetapkan oleh guru. Pembelajaran berbasis student centered merupakan salah satu pendekatan yang dapat diimplementasikan untuk memperoleh kefektifan pembelajaran. Dengan demikian, kualitas pembelajaran ditentukan oleh keterampilan guru dalam mengorganisasikan bahan ajar, media, integrasi ICT yang sesuai dengan konteks student centered learning (Nazeer et al., 2018). Bahan ajar dapat dikembangkan sesuai dengan kebutuhan, karakteristik siswa dan materi pembelajaran yang akan disajikan.

Sejalan dengan perkembangan tuntutan abad 21, guru dituntut untuk kreatif dan inovatif dalam memilih dan mengembangkan bahan ajar yang berkualitas. Format bahan ajar berupa modul dapat dipilih oleh guru. Modul yang mengadaptasi pembelajaran berbasis eksplorasi dan investigasi menggunakan peralatan yang sesuai seperti seorang saintis dapat menstimulasi dan mendorong rasa ingintahu, sekaligus aktif untuk bertanya maupun mengemukakan gagasan (Dumitrescu, Lucian, \& Monica, 2014; Widiyawati, 2017). Beberapa penelitian terdahulu mengenai pengembangan modul memberikan gambaran bahwasannya modul yang layak dan memenuhi kriteria tertentu dapat meningkatkan kualitas pembelajaran IPA (Sari \& Jusar, 2018; B. Setiawan, Innatesari, Sabtiawan, \& Sudarmin, 2017). Mulyasa (2010) menyatakan bahwa modul merupakan bahan belajar mandiri yang berupa serangkaian pengalaman belajar yang direncanakan dan dirancang secara berurutan untuk membantu siswa mencapai tujuan pembelajaran. Modul terdiri dari materi, metode, dan penilaian yang dikemas semenarik mungkin untuk mencapai kompetensi yang diharapkan (Prihatnawati, Amin, \& AlMuhdar, 2018). Melalui penggunaan modul siswa dapat belajar bertanggung jawab terhadap kegiatan belajarnya, selain itu pembelajaran dengan modul bisa mengatasi perbedaan kemampuan setiap siswa.

Dalam konteks pembelajaran IPA, format modul yang inovatif dan sesuai dengan karakteristik disiplin ilmu ini menjadi begitu penting untuk digunakan. IPA selalu menyajikan fenomena, teknologi dan proses yang ditemui dalam kehidupan sehari-hari sehingga penting untuk mengemasnya dalam format yang menarik untuk memotivasi siswa dalam belajar (Dumitrescu et al., 2014). Modul yang mengintegrasikan scientific approach sebagai salah satu ciri khas IPA dapat memfasilitasi student centered learning. Scientific approach sebagai representasi karakter IPA ini memposisikan guru sebagai fasilitator dalam kegiatan siswa melakukan investigasi maupun pembuktian ilmiah melalui prosedur-prosedur yang sistematis untuk menemukan konsep, teori, hukum maupun prinsip (Istuningsih, Baedhowi, \& Sangka, 2018). Tahap mengamati, menanya, mengeksplorasi, mengasosiasi dan mengkomunikasikan yang merupakan tahapan scientific approach pada dasarnya mengajarkan siswa untuk melakukan metode ilmiah (Yustyan, Widodo, \& Pantiwati, 2015).

Diperlukan media yang tepat untuk dikombinasikan dengan format modul berbasis scientific approach agar keterampilan proses sains maupun hasil belajar dan siswa meningkat. Crossword puzzle merupakan media yang dapat disisipkan dalam modul. Beberapa disiplin ilmu seperti kesehatan, sosiologi, psikologi dan biologi diketahi telah menerapkan crossword puzzle sebagai suatu media pembelajaran yang efektif untuk memberikan ruang kepada siswa untuk berfikir secara kritis, kolaboratif, dan terampil dalam berkomunikasi (Nazeer et al., 
2018; Saran \& Kumar, 2015). Beberapa penelitian mengenai pengembangan modul berbasis scientific approach telah banyak dilakukan (Ali, Sunarno, \& Sukarmin, 2015; Diani et al., 2019; Firman, Baedhowi, \& Murtini, 2018; Setiyadi, Ismail, \& Gani, 2017) tetapi belum ada penelitian yang mengkombinasikan modul dengan crossword puzzle.

Sesuai dengan karakteristik pembelajaran Biologi dibutuhkan pengolahan materi pembelajaran untuk membangun konsep secara mandiri, kemampuan berpikir kritis, analisis dan mensintesis informasi yang didapatkan. Salah satu materi pembelajaran Biologi yang perlu pemahaman konsep secara kontekstual adalah materi zat adiktif dan psikotropika sebab berhubungan langsung dengan kehidupan sehari-hari siswa. Dengan demikian, perlu penekanan dan penguatan bagi siswa terhadap pemahaman materi zat adiktif dan psikotropika, agar siswa bisa mengembangkan kehidupan yang akan dihadapi dimasa depan nanti. Oleh sebab itu, tujuan penelitian ini yaitu untuk menghasilkan serta mengetahui validitas an praktikabilitas modul pembelajaran berbasis scientific approach dengan variasi crossword puzzle p ada materi zat adiktif dan psikotropika bagi siswa kelas VIII SMP.

\section{METODE}

\section{Jenis Penelitian}

Penelitian ini merupakan penelitian pengembangan (Research and Developmet) yang mengadaptasi model pengembangan ADDIE (Analysis, Design, Development, Implementation and Evaluation) (Azimi, Amadigol, \& Rasegarpour, 2015; Dick \& Carey, 2000). Model pengembangan ADDIE disajikan dalam Gambar 1.

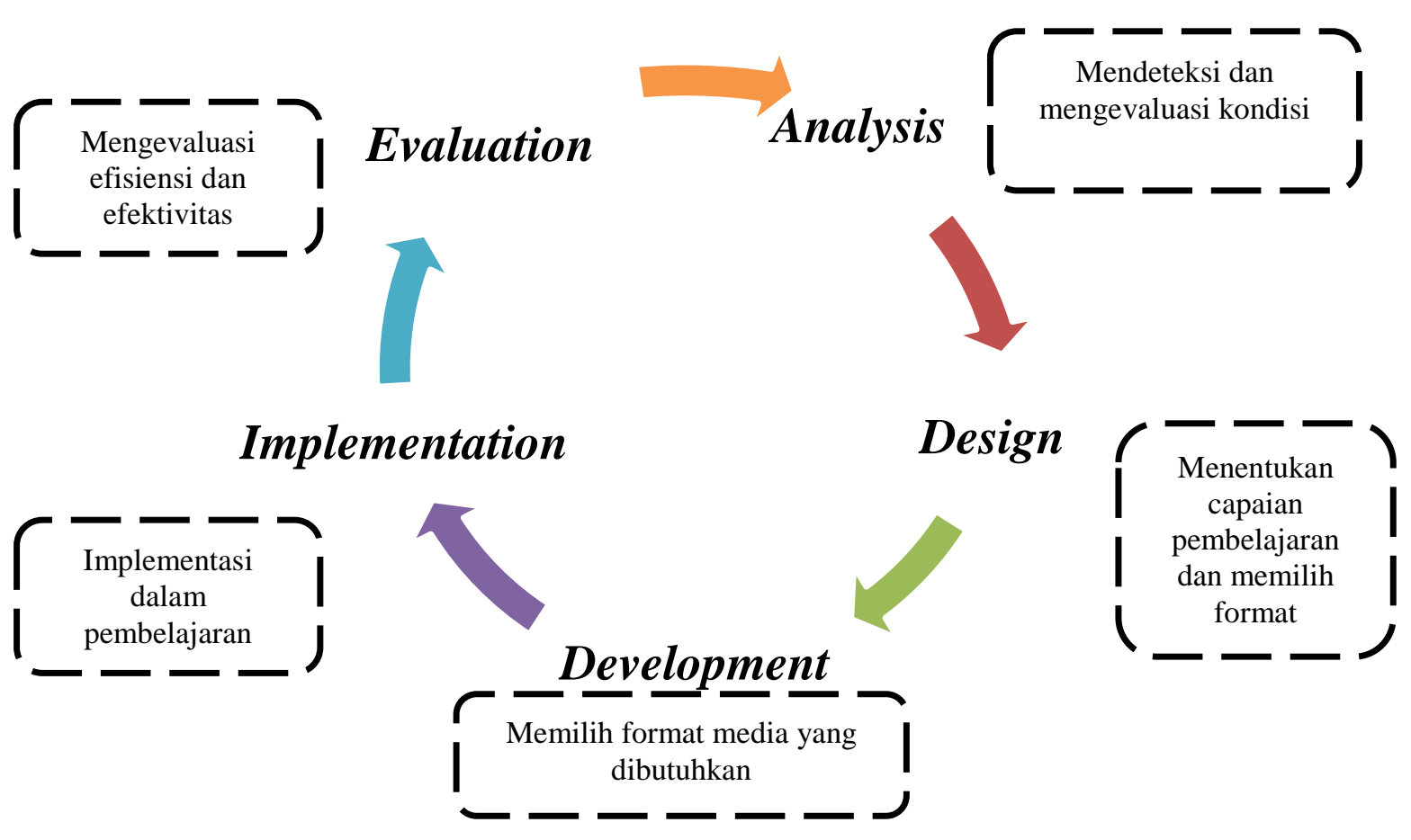

Gambar 1. Model pengembangan ADIIE 


\section{Waktu dan Tempat Penelitian}

Penelitian ini dilaksanakan semester Ganjil TA 2018/2019, bertempat di SMP N 2 Kapur IX.

\section{Subjek Penelitian}

Subjek penelitian siswa SMP kelas VIII, diambil satu kelas untuk uji coba produk modul yaitu kelas $\mathrm{VIII}_{2}$ yang berjumlah 30 orang.

\section{Prosedur}

Prosedur pengembangan dalam penelitian ini mengikuti langkah-langkah yang ada dalam model pengembangan ADDIE tetapi hanya dibatasi pada tingga langkah yaitu analyse, design development dan implementation. Skema pengembangan modul ini secara ringkas disajikan dalam Gambar 2.

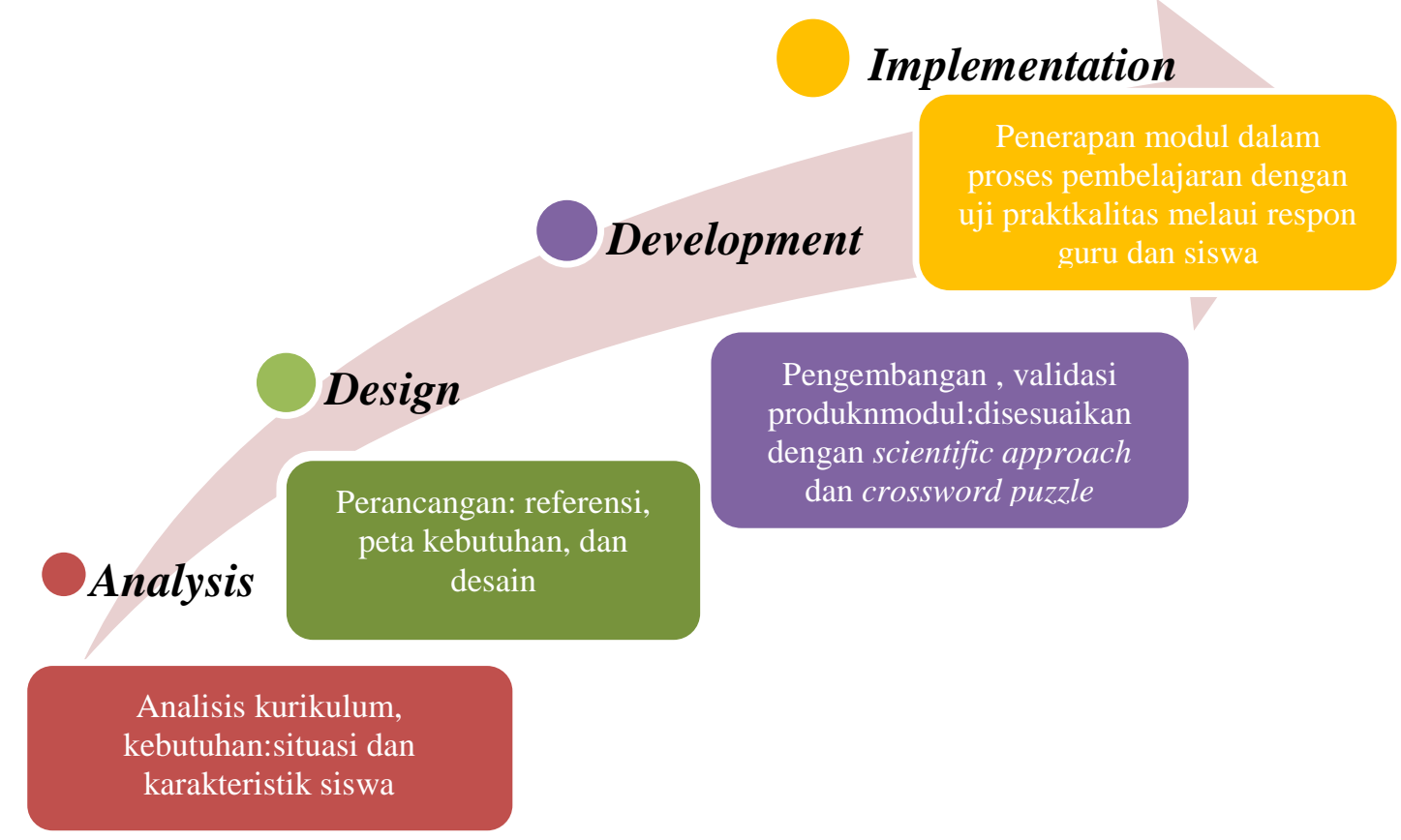

Gambar 2. Skema prosedur pengembangan modul berbasis scientific approach dengan ADIIE model

\section{Analysis (analisis)}

Tahap analisis ini bertujuan untuk mendefenisikan dan menetapkan secara jelas syaratsyarat pengembangan modul. Langkah-langkah pada tahap analisis yaitu berupa analisis kurikulum 2013, analisis kebutuhan (analisis situasi untuk mengetahui situasi sekolah yang dijadikan tempat penelitian dan analisis karakteristik siswa bertujuan untuk mengidentifikasi karakteristik siswa sesuai dengan jenjang pendidikannya), dan analisis konsep.

\section{Design (perancangan)}

Tahap design adalah tahap perancangan modul. Langkah-langkah yang dilakukan pada tahap desain adalah (1) menyediakan buku referensi yang berkaitan dengan materi zat adiktif 
dan psikotropika, serta buku tentang scientific approach \& crossword puzzle; (2) menyusun peta kebutuhan untuk pengembangan modul; (3) penyusunan desain modul, dilakukan dengan cara: menentukan judul modul, menentukan desain (perumusan KD), perancangan dari segi media, penyusunan topik materi, menentukan bentuk evaluasi; (4) penyusunan desain instrumen.

\section{Development (pengembangan)}

Tahap development bertujuan untuk memproduksi modul pembelajaran yang akan digunakan dalam proses pembelajaran untuk mencapai tujuan pembelajaran yang sudah dirumuskan sebelumnya, dan memilih media atau kombinasi media yang akan digunakan untuk mencapai tujuan pembelajaran. Validasi pakar dilakukan pada tahap ini untuk mengetahui kelayakan modul dari aspek didaktik (aspek materi), aspek konstruksi (aspek bahasa dan keterbacaan), aspek teknis (penyajian).

Modul yang telah dirancang dan dikembangkan, selanjutnya divalidasi oleh empat orang validator atau pakar yaitu dosen program studi pendidikan Biologi Universitas Negeri Riau, dosen program studi pendidikan Biologi ST-KIP Abdi Pendidikan Payakumbuh, dan dua orang guru Biologi SMPN 2 Kapur IX yang bertujuan untuk melihat kelayakan dari modul yang telah di kembangkan. Hasil validasi, modul diperbaiki sesuai saran dari para pakar untuk selanjutnya dilakukan uji kepraktisan oleh guru dan siswa.

\section{Implementation (implementasi)}

Modul yang telah divalidasi oleh pakar selanjutnya diujikan kepada guru dan siswa untuk mengetahui kepraktisan dalam penggunaan. Aspek-aspek yang diujikan dalam angket respon praktikalitas modul berbasis scientific approach dengan crossword puzzle pada materi zat adiktif dan psikotropika yaitu kemudahan penggunaan, efisiensi waktu pembelajaran serta manfaat modul.

\section{Instrumen dan Teknik Pengumpulan Data}

Teknik analisis data yang digunakan untuk penelitian pengembangan ini adalah kuantitatif-deskriptif berupa rerata dan persentase. Instrumen berupa lembar validasi dan lembar respon praktikalitas modul oleh guru dan siswa digunakan dalam penelitian ini.

\section{Analisis data validasi pakar}

Analisis data validasi dari pakar terhadap seluruh aspek yang dinilai dicari persentase dengan menggunakan persamaan 1 .

$$
P=\frac{f}{N} \times 100 \%
$$

Keterangan:

$\mathrm{P} \quad=$ Angka persentase

$\mathrm{N} \quad=$ Number of cases (jumlah frekuensi yang diberikan validator)

$\mathrm{f} \quad=$ Skor item (Sudijono, 2012) 
Data validasi modul berupa nilai mulai dari 1 sampai 4. Data ini kemudian dianalisis dengan kriteria yang disajikan pada Tabel 1 .

Tabel 1. Pengkategorian hasil validasi pakar

\begin{tabular}{cc}
\hline Rerata Skor & Kriteria \\
\hline $\mathbf{1 , 0 0}<\overline{\mathbf{X}} \leq \mathbf{1 , 9 9}$ & Tidak Valid \\
$\mathbf{1 , 9 9}<\overline{\mathbf{X}} \leq 2,99$ & Kurang Valid \\
$2,99<\overline{\mathbf{X}} \leq 3,49$ & Valid \\
$3,49<\overline{\mathbf{X}} \leq \mathbf{4 . 0 0}$ & Sangat Valid \\
\hline
\end{tabular}

\section{Analisis Data Penilaian Guru dan Siswa}

Data tentang respons praktikalitas oleh guru dan siswa terhadap penggunaan modul dalam proses pembelajaran dianalisis dengan menggunakan persentase $(\%)$ yang disajikan dalam persamaan (2).

$$
\mathrm{P}=\frac{n}{N} \times 100 \%
$$

Keterangan:

$\mathrm{P}=$ Angket persentase yang ingin didapatkan

$\mathrm{n}=$ Jumlah guru/siswa yang memberikan penilaian

$\mathrm{N}=$ Total jumlah guru/siswa (Purwanto, 2010)

Data persentase yang diperoleh dilakukan pengelompokkan sesuai kriteria dalam Tabel 2.

Tabel 2. Pengkategorian hasil respon praktikalitas guru dan siswa

\begin{tabular}{cc}
\hline Skor & Kriteria \\
\hline $\mathbf{9 0}<\boldsymbol{X} \leq \mathbf{1 0 0}$ & Sangat Praktis \\
$\mathbf{8 0}<\boldsymbol{X} \leq \mathbf{9 0}$ & Praktis \\
$\mathbf{6 5}<\boldsymbol{X} \leq \mathbf{8 0}$ & Cukup Praktis \\
$\mathbf{5 5}<\boldsymbol{X} \leq \mathbf{6 5}$ & Tidak Praktis \\
$\mathbf{0}<\boldsymbol{X} \leq \mathbf{5 5}$ & Sangat Tidak Praktis \\
\hline
\end{tabular}

\section{Data, Intrumen, dan Teknik Pengumpulan Data}

Data dalam penelitian ni dijaring melalui teknik angket dengan menggunakan instrumen lembar validasi pakar dan angket respon guru maupun siswa atas modul berbasis scientific approach dengan variasi crossword puzzle hasi pengembangan. Data hasil validasi selanjutnya digunakan sebagai acuan untuk melakukan evaluasi dalam penentuan kriteria valid atau tidaknya modul. Hasil respon guru maupun siswa berfungsi untuk menggali data mengenai kepraktisan modul. 


\section{HASIL DAN PEMBAHASAN}

Pembelajaran yang berorientasi pada pengembangan aktivitas siswa harus didasarkan pada pembelajaran student-centered. Guru hanya bertugas mengendalikan jalannya pembelajaran melalui proses penrencanaan, pelaksanaan dan evaluasi secara optimal. Keberadaan bahan ajar berupa modul akan membantu mencapai pembelajaran yang efektif. Oleh sebab itu, guru harus kreatif dan inovatif dalam menyusun modul yang tepat sesuai dengan karakter siswa maupun materi ajar.

Modul berbasis scientific approach yang telah dikembangkan dengan mengadaptasi model ADDIE pada topik zat adiktif dan psikotoropika bagi kelas VIII SMP terdiri dari peta konsep, deskripsi kompetensi yang ingin dicapai, penjabaran materi, kegiatan mandiri berupa praktikum, evaluasi dan crossword puzzle. Integrasi scientific approach dalam modul ini dikemas melalui kehadiran kegiatan pembelajaran berorientasi pada kegiatan praktikum mandiri. Praktikum mengajarkan siswa untuk melakukan eksplorasi, investigasi dan pembuktian ilmiah melalui tahapan-tahapan sistematis (Diani et al., 2019; Widiyawati \& Nurwahidah, 2018). Tampilan modul yang telah dikembangkan disajikan dalam Gambar 3.
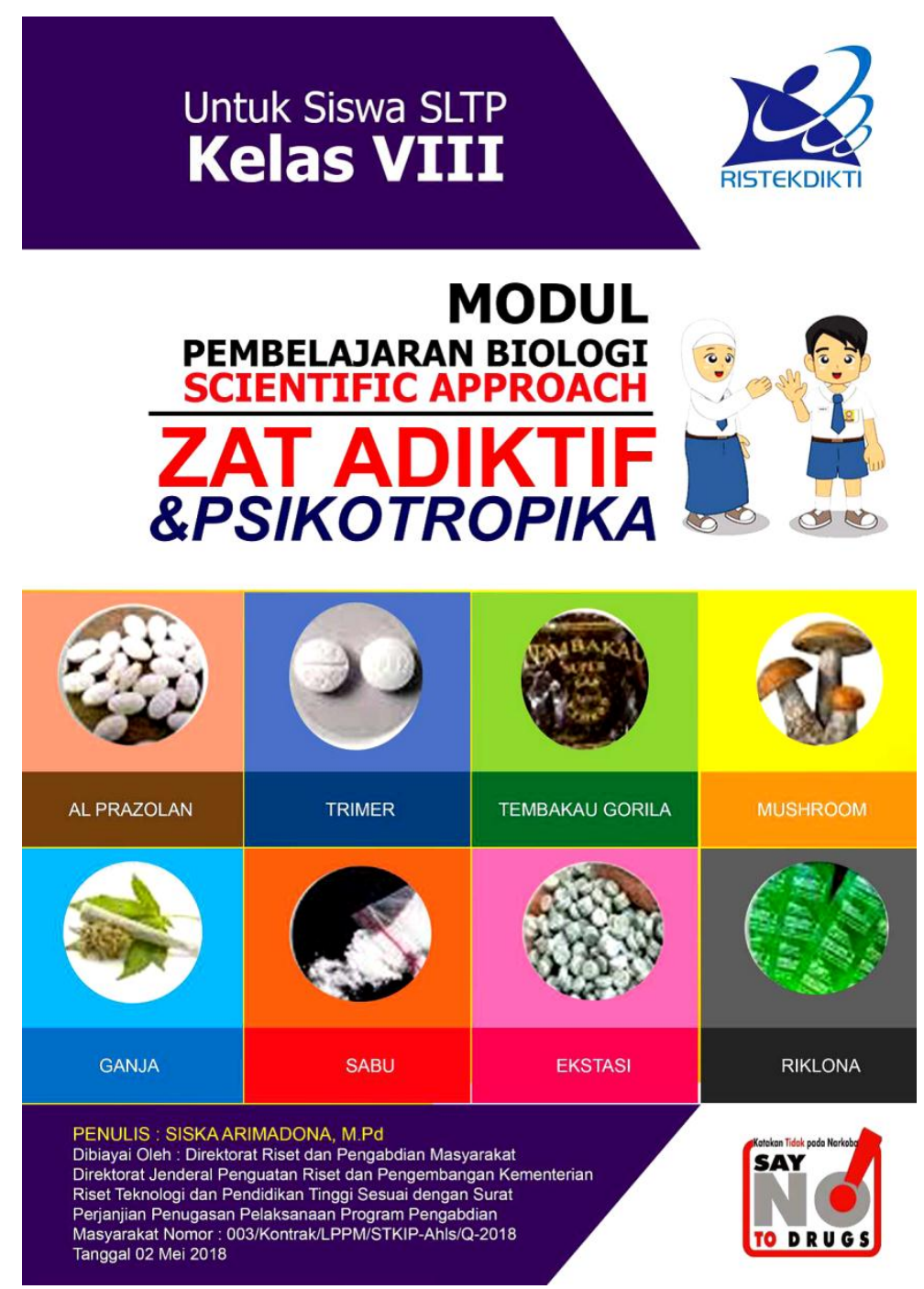

Gambar 3. Tampilan halaman sampul modul 
Syarat didaktik sebuah modul yaitu tersedianya kompetensi yang harus dicapai setelah mempelajari modul tersebut. Contoh tampilan kompetensi inti (KI), kompetensi dasar (KD), serta indikator pencapaian kompetensi pada materi zat adiktif dan psikotropika disajikan dalam Gambar 4. Kompetensi yang ingin dicapai harus tercermin dalam materi maupun kegiatan mandiri dan crossword puzzle.

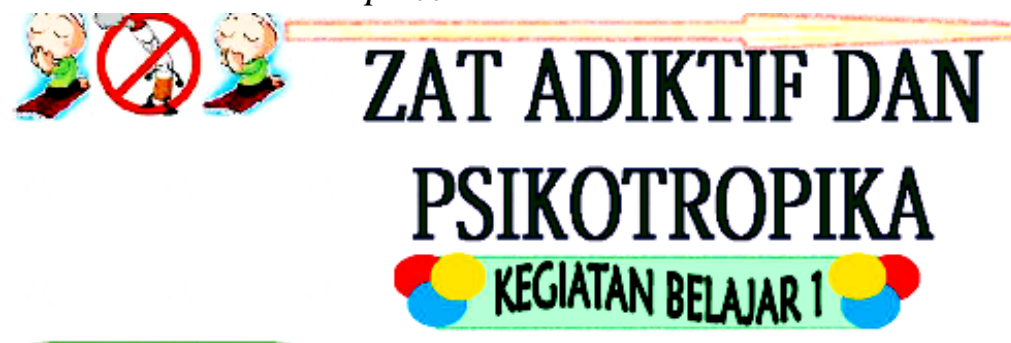

Kompetensi Inti:

Kl.1 : Menghayati dan mengamalkan ajaran agama yang dianutnya.

$\mathrm{KI} .2$ : Mengembangkan perilaku (jujur, disiplin, tanggungjawab, peduli, santun, ramah lingkungan, gotong royong, kerjasama, cinta damai, responsif dan pro-aktif) dan menunjukkan sikap sebagai bagian dari solusi atas berbagai permasalahan bangsa dalam berinteraksi secara efektif dengan lingkungan sosial dan alam serta dalam menempatkan diri sebagai cerminan bangsa dalam pergaulan dunia.

$\mathrm{KI} .3$ : Memahami dan menerapkan pengetahuan (faktual, konseptual, dan prosedural) berdasarkan rasa ingin tahunya tentang ilmu pengetahuan, teknologi, seni, budaya terkait fenomena dan kejadian tampak mata.

Kl.4 : Mengolah, menyaji, dan menalar dalam ranah konkret (menggunakan, mengurai, merangkai, memodifikasi, dan membantu) dan ranah abstrak (menulis, membaca, menghitung, menggambar, dan menggambar, dan mengarang) sesuai dengan yang dipelajari di sekolah dan sumber lain yang sama dalam sudut pandang/teori.

Kompetensi Dasar dan Indikator Pencapaian Kompetensi:

3.6 Memahami berbagai zat adiktif dalam makanan \& minuman serta dampaknya terhadap kesehatan.

3.6.1 Menjelaskan macam dan efek penggunaan bahan adiktif bagi kesehatan.

Gambar 4. Tampilan KI, KD dan indikator pencapaian kompetensi pada modul

Scientific approach merupakan pendekatan pembelajaran yang dianjurkan sesuai Kurikulum 2013 yang meliputi tahapan 5M yaitu mengamati, menanya, mengeksplorasi, mengasosiasi dan mengkomunikasikan (Widiyawati, 2017). Pembelajaran berbasis scientific approach mampu menciptakan suasana belajar aktif yang mendukung kreativitas dan inovasi siswa dalam menghadapi materi ajar (Firman et al., 2018). Kegiatan ini menyuguhkan pengalaman belajar sesuai situasi dunia nyata yang dapat mendukung performa mereka dalam berkomunikasi, berinteraksi, dan memberikan argumentasi atas permasalahan yang sedang diselesaikan (Dewitt, Siraj, \& Alias, 2014; Prabowo, Ibrohim, \& Saptasari, 2016). Diskusi sebagai salah satu cara siswa berinteraksi dalam kelompok untuk melakukan asosiasi atas temuan-temuannya akan berpengaruh terhadap proses mereka mengkonstruksi kalimat dan frase yang lebih bermakna (Dewitt et al., 2014). Hal ini senada dengan penelitian yang telah dilakukan oleh Setiawan \& Wilujeng (2016) bahwa penerapan instrumen berbasis scientific approach dapat meningkatkan keterampilan proses dan hasil belajar kognitif siswa. Tampilan 
petunjuk praktikum untuk mengakomodasi scientific approach dalam modul hasil pengembangan disajikan dalam Gambar 5.

\section{AYO LAKUKAN!!}

* Melakukan identifikasi dengan mengamati makanan dan minuman yang dijual disekolah yang sudah dibeli dan dibawa ke kelas. (seperti: snack, gorengan, minuman kemasan, es, teh hangat, serta berbagai makanan dan minuman dalam kemasan).

\begin{tabular}{|l|l|l|l|l|}
\hline \multicolumn{1}{|c|}{$\begin{array}{c}\text { Bahan } \\
\text { Makanan }\end{array}$} & Jenis Makanan & Tampilan & Warna & Rasa \\
\hline Snack & Chitato & & \\
\hline & Borobudur & & \\
\hline Gorengan & Taro. dll & \\
\hline & Bakwan & \\
\hline Minuman & Tahu & \\
\hline & Pisang . dll \\
\hline & Teh es & \\
\hline & Pop Ice \\
\hline
\end{tabular}

Dari identifikasi dan pengamatan yang anda lakukan dapatkah anda mengetahui makanan yang mengandung zat adiktif. Dan buatlah kesimpulannya!

* Analisis Bahan Utama dan Bahan Tambahan dalam Makanan

\begin{tabular}{|l|l|l|l|l|l}
\hline $\begin{array}{c}\text { Bahan } \\
\text { Makanan yag } \\
\text { Dijual di } \\
\text { Sekolah }\end{array}$ & Jenis Makanan & Rasa & Tampilan & Keawetan & Bumbu \\
\hline Daging & Sosis & & & \\
\hline & Sate & & & \\
\hline
\end{tabular}

Gambar 5. Tampilan petunjuk praktikum

Modul dalam penelitian ini divariasikan dengan crossword puzzle pada bagian akhir. Teori pembelajaran konstruktivisme menekankan manfaat dari penggunaan crossword puzzle sebagai game edukatif yang dapat memanipulasi aktivitas siswa dalam menguasai suatu konsep (Rahmawati, 2018). Crossword puzzle terdiri dari kotak-kotak yang tersusun secara mendatar maupun menurun dan dapat diselesaikan berdasarkan pertanyaan yang telah disajikan. Tampilan crossword puzzle disajikan dalam Gambar 6. 


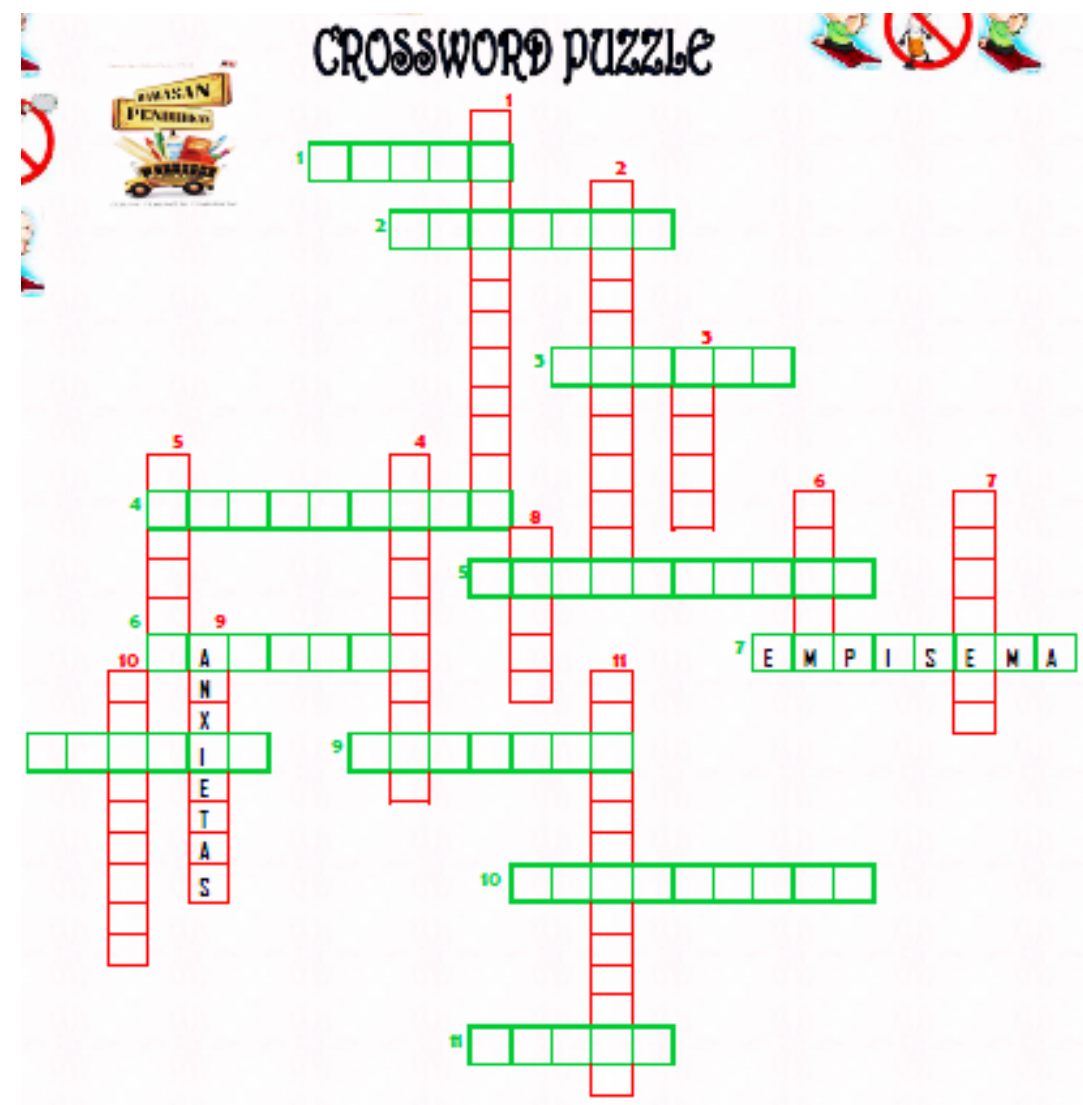

\footnotetext{
SOAL MENDATAR: (hijau)

1. ..... bahasa latinnya adalah Cannabis Sativa.

2. Salah satu obat penenang yang mengandung amfetamin adalah.....

3 Nama kimia alkhnhol arialah
}

Gambar 6. Contoh tampilan crossword puzzle dalam modul

\section{Praktikalitas Modul oleh Guru dan Siswa}

Data praktikalitas diperoleh dari uji praktikalitas modul pembelajaran biologi materi zat adiktif dan psikotropika berbasis scientific approach dengan variasi crossword puzzle oleh guru dan siswa. Praktikalitas modul diperoleh dari aspek yaitu kemudahan penggunaan, efisiensi waktu pembelajaran, dan manfaat penggunaan modul. Kriteria praktis merujuk pada kesesuaian tujuan perancangan dengan penggunaan modul (van den Akker, Bannan, Kelly, Nieveen, \& Plomp, 2013). Hasil analisis data praktikalitas modul oleh guru disajikan dalam Tabel 3.

Tabel 3. Hasil analisis data praktikalitas modul pembelajaran biologi oleh guru

\begin{tabular}{clcl}
\hline \multirow{2}{*}{ No. } & Aspek Praktikalitas & $\begin{array}{c}\text { Rerata Persentase Skor } \\
(\mathbf{\%})\end{array}$ & Kriteria \\
\hline 1 & Kemudahan penggunaan & 91,66 & Sangat praktis \\
2 & Efesiensi waktu pembelajaran & 100,00 & Sangat praktis \\
3 & Manfaat & 87,50 & Praktis \\
& \multirow{2}{*}{ Total } & 279,16 & \\
& Rata-rata & 93,05 & Sangat praktis \\
\hline
\end{tabular}


Besarnya rerata persentase skor mengenai aspek praktikalitas oleh guru menunjukkan bahwa modul yang dikembangkan masuk dalam kriteria sangat praktis. Dengan demikian modul yang dikembangkan praktis untuk dapat membantu dan mempermudahkan guru dalam memfasilitasi pembelajaran yang berbasis pada scientific approach. Sebagai tambahan, modul pembelajaran biologi ini juga dapat memberikan manfaat untuk dapat mengefisienkan waktu dalam penyampaian materi pembelajaran. Tabel 4 menampilkan hasil uji praktikalitas modul oleh siswa.

Tabel 4. Hasil uji praktikalitas modul pembelajaran biologi oleh siswa

\begin{tabular}{clcl}
\hline No. & \multicolumn{1}{c}{ Aspek } & Rerata Persentase Skor (\%) & \multicolumn{1}{c}{ Kriteria } \\
1 & Kemudahan penggunaan & 81,90 & Praktis \\
2 & Efesiensi waktu pembelajaran & 80,08 & Praktis \\
3 & Manfaat & 80,00 & Praktis \\
& Total & 241,98 & \\
& Rata-rata & 80,66 & Praktis \\
\hline
\end{tabular}

Tabel 4 menyatakan bahwa rerata persentase skor praktikalitas oleh siswa yaitu sebesar $80,66 \%$ dan termasuk kriteria praktis. Hasil analisis praktikalitas modul oleh siswa menunjukkan bahwa secara keseluruhan modul pembelajaran biologi berbasis scientific approach dengan variasi crossword puzzle ini disenangi dan dapat menarik minat siswa untuk mengikuti pembelajaran. Modul yang dikombinasikan dengan crossword puzzle membuat siswa belajar semakin tinggi. Berdasarkan penelitian, terdapat pengaruh positif meningkatnya minat media terhadap hasil belajar siswa (Wahyuni, 2018). Penelitian Saran \& Kumar (2015) mengungkapkan bahwa penggunaan crossword puzzle dapat menciptakan atmosfer belajar yang nyaman bagi siswa sehingga mereka dapat produktif dalam menguasai materi ajar. Siswa dituntut menyelesaikan puzzle dan berusaha mengisi seluruh kotak yang tersedia dengan kemungkinan-kemungkinan jawaban yang ada (Nicosia, Barlacchi, \& Moschitti, 2015). Dengan demikian secara otomatis crossword puzzle dapat mengasah penguasaan kosakata serta konsep terkait zat adiktif dan psikotropika.

\section{SIMPULAN DAN SARAN}

\section{Simpulan}

Dapat disimpulkan bahwa modul berbasis scientific approach dengan variasi crossword puzzle yang telah dikembangkan dengan model ADDIE termasuk dalam kriteria valid dan praktis sehingga dapat digunakan dalam pembelajaran pada materi zat adiktif dan psikotropika. 


\section{Saran}

Berdasarkan penelitian yang telah dilakukan, dapat disarankan untuk melakukan pengembangan modul dalam format digital sehingga lebih mudah dalam proses implementasi maupun penyebarluasan produk.

\section{UCAPAN TERIMAKASIH}

Peneliti mengucapkan terimakasih kepada Kemenristekdikti atas support dana penelitian ini dalam Hibah Penelitian dan Pengabdian tahun 2018 pada skema Penelitian Dosen Pemula.

\section{DAFTAR PUSTAKA}

Ali, M., Sunarno, W., \& Sukarmin, S. (2015). Pengemabngan modul IPA berbasis karakter islami melalui pendekatan saintifik pada tema rotasi dan revolusi bumi sebagai implementasi kurikulum 2013. Jurnal Inkuiri, 4(2), 57-67. Retrieved from http://jurnal.fkip.uns.ac.id/index.php/sains

Azimi, K., Amadigol, J., \& Rasegarpour, H. (2015). A survey of the effectiveness of instructional design ADDIE and multimedia on learning key skills of futsal. Journal of Educational and Management Studies, 5(3), 180-186. Retrieved from http://journal2.um.ac.id/index.php/jpg/

Dewitt, D., Siraj, S., \& Alias, N. (2014). Collaborative mLearning: A module for learning secondary school science. Educational Technology \& Society, 17(1), 89-101. Retrieved from https://www.jstor.org/stable/pdf/jeductechsoci.17.1.89.pdf?acceptTC=true\& coverpage $=$ false

Diani, R., Kesuma, G. C., Diana, N., Yuberti, Y., Anggraini, R. D., \& Fujiani, D. (2019). The development of physics module with the scientific approach on islamic literacy. Journal of Physics: Conference Series 1155 (2019) 012034, 1155. https://doi.org/10.1088/17426596/1155/1/012034

Dick, W., \& Carey, L. (2000). The systematic design of instruction (5th ed.). New York: Addison-Wesley.

Dumitrescu, C., Lucian, R., \& Monica, L. (2014). Learning chemistry in the frame of integrated science modules - Romanian students ' perception. In Procedia - Social and Behavioral Sciences (Vol. 116, pp. 2516-2520). Elsevier B.V. https://doi.org/10.1016/j.sbspro.2014.01.603

Firman, F., Baedhowi, B., \& Murtini, W. (2018). Efektivitas pendekatan saintifik untuk meningkatkan hasil belajar siswa. Forum Ilmu Sosial, 45(1), 1-9. https://doi.org/https://doi.org/10.15294/fis.v44i1.12987

Istuningsih, W., Baedhowi, B., \& Sangka, K. B. (2018). The Effectiveness of scientific approach using e-module based on learning cycle7E to improve students' learning outcome. International Journal of Educational Research Review, 3(3), 75-85. Retrieved from https://dergipark.org.tr/download/article-file/516371

Mulyasa, M. (2010). Implementasi kurikulum. Bandung: PT Remaja Rosdakarya.

Nazeer, M., Sultana, R., Ahmed, M. M., Asad, M. R., Sami, W., Hattiwale, H. R., \& Sreekanth, T. (2018). Crossword puzzles as an active learning mode for student directed 
learning in anatomy teaching: medical undergraduate perceptions. International Journal of Medical Research \& Health Sciences, 7(10), 12-19.

Nicosia, M., Barlacchi, G., \& Moschitti, A. (2015). Learning to rank aggreagated answers for crossword puzzles. In European Conference on Information Retrieval (pp. 556-561). Springer, Cham. https://doi.org/https://doi.org/10.1007/978-3-319-16354-3_61

Prabowo, C. A., Ibrohim, I., \& Saptasari, M. (2016). Pengembangan modul pembelajaran inkuiri berbasis laboratorium virtual. Jurnal Pendidikan: Teori, Penelitian, Dan Pengembangan, 1(6), 1090-1097. https://doi.org/http://dx.doi.org/10.17977/jp.v1i6.6422

Prihatnawati, Y., Amin, M., \& Al-Muhdar, M. H. I. (2018). The effect of module implementation with STAD cooperative learning toward process skills in science and cognitive achievement of 8th grade students. In International Conference on Learning Innovation (ICLI 2017) (Vol. 164, pp. 111-116). https://doi.org/https://dx.doi.org/10.2991/icli-17.2018.22

Purwanto, N. (2010). Prinsip-prinsip dan teknik evaluasi pengajaran. Bandung: PT Remaja Rosdakarya.

Rahmawati, A. (2018). The use of computer-based interactive game to make the imaginary logic of structural analysis more real. Journal of Turksish Science Education, 15(December), 1-12. https://doi.org/10.12973/tused.10251a

Saran, R., \& Kumar, S. (2015). Use of crossword puzzle as a teaching aid to facilitate active learning in dental materials. Indian Journal of Applied Research, 5(4), 456-457. Retrieved from https://www.researchgate.net/profile/Saurabh_Kumar161/publication/320891742_Use_o f_crossword_puzzle_as_a_teaching_aid_to_facilitate_active_learning_in_dental_materia 1s_Medical_Science/links/5a012b38a6fdcc82a317bc1a/Use-of-crossword-puzzle-as-ateaching-aid-to-facilitate-active-learning-in-dental-materials-Medical-Science.pdf

Sari, R. T., \& Jusar, I. R. (2018). Analysis of science learning process by using learning module of character education oriented through quantum learning approach. Jurnal Penelitian Dan Pembelajaran IPA, 4(1), 14-24. https://doi.org/10.30870/jppi.v4i1.2252

Setiawan, B., Innatesari, D. K., Sabtiawan, W. B., \& Sudarmin, S. (2017). The development of local wisdom-bsed natural science module to improve science literation of students. Jurnal Pendidikan IPA Indonesia, 6(1), 49-54. https://doi.org/10.15294/jpii.v6i1.9595

Setiawan, D., \& Wilujeng, I. (2016). The development of scientific-approach-based learning instruments integrated with red onion farming potency in Brebes Indonesia. Jurnal Pendidikan IPA, 5(1), 22-30. https://doi.org/10.15294/jpii.v5i1.5785

Setiyadi, M. W., Ismail, I., \& Gani, H. A. (2017). Pengembangan modul pembelajaran biologi berbasis pendekatan saintifik untuk meningkatkan hasil belajar siswa. Journal of Educational Science and Technology, 3(2), 102-112. https://doi.org/https://doi.org/10.26858/est.v3i2.3468

Sudijono, A. (2012). Pengantar statistik pendidikan. Jakarta: PT Raja Grafindo Persada.

van den Akker, J., Bannan, B., Kelly, A. E., Nieveen, N., \& Plomp, T. (2013). Educational Design Research Part (a): An introduction. Enschede: Enschede, the Netherlands: Netherlands Institute for Curriculum Development (SLO).

Wahyuni, A. (2018). Pengaruh penggunaan Maple sebagai media pembelajaran pada mata 
kuliah kalkulus lanjut. In Seminar Nasional Edusaintek (pp. 9-13). Semarang: FMIPA Universitas Muhammadiyah Semarang.

Widiyawati, Y. (2017). Pemanfaatan media pembelajaran IPA bagi peserta didik visual impairment di SLB. JIPVA (Jurnal Pendidikan IPA Veteran), 1(1), 9-23. Retrieved from http://e-journal.ivet.ac.id/index.php/jipva/article/view/510

Widiyawati, Y., \& Nurwahidah, I. (2018). Elclivs berbasis inquiry untuk meningkatkan penguasaan konsep siswa tuna netra pada materi rangkaian listrik. Jurnal Inovasi Pendidikan IPA, 4(2), 212-223. https://doi.org/https://doi.org/10.21831/jipi.v4i2.21527

Yustyan, S., Widodo, N., \& Pantiwati, Y. (2015). Peningkatan kemampuan berpikir kritis dengan pembelajaran berbasis scientific approach siswa kelas X SMA Panjura Malang. JPBI (Jurnal Pendidikan Biologi Indonesia), 1(2), 240-254. https://doi.org/https://doi.org/10.22219/jpbi.v1i2.3335

\section{PROFIL SINGKAT}

Siska Arimadona, M.Pd lahir di Sialang Bawah pada 12 Februari 1986. Pada tahun 2009 menyelesaikan S1 Program Studi Pendidikan biologi di Universitas Negeri Padang. Pada tahun 2011 menyelesaikan S2 Program Studi Teknologi Pendidikan Konsentrasi Pendidikan Biologi Universitas Negeri Padang. Saat ini aktif sebagai dosen di Prodi Pendidikan Biologi STKIP Ahlussunnah Bukittinggi.

Rini Silvina, M.Pd lahir di Padang Sibusuk pada 8 Januari 1991. Pada tahun 2013 menyelesaikan S1 Program Studi Pendidikan Biologi STKIP PGRI Sumatera Barat. Pada tahun 2016 menyelesaikan S2 Program Studi Pendidikan Biologi di STKIP PGRI Sumatera Barat. Saat ini aktif sebagai dosen di Prodi Pendidikan Biologi STKIP Ahlussunnah Bukittinggi. 